\title{
INFLUENCE OF TERTIARY INSTITUTIONS ON THE GROWTH AND DEVELOPMENT OF A TYPICAL RURAL LOCAL GOVERNMENT AREA IN NIGERIA
}

\author{
Adewale Mukhtar OLAYIWOLA* \\ Department of Geography, Obafemi Awolowo University Ile-Ife, Nigeria, \\ e-mail: olaadewale1@gmail.com amolayiwola@oauife.edu.ng
}

Tesini Precious DOMBO

African Regional Institute for Geospatial Science and Technology (AFRIGIST) Obafemi Awolowo University Ile-Ife, Nigeria, e-mail: dombo.tesini@gmail.com

\begin{abstract}
Citation: Olayiwola, A. M., Dombo. T. P. (2019). Influence of Tertiary Institutions on the Growth and Development of a Typical Rural Local Government Area in Nigeria. Analele Universităţii din Oradea, Seria Geografie, $29(2)$ : $18-29$. https://doi.org/10.30892/auog.292102-801
\end{abstract}

\begin{abstract}
This study assessed the impact of locating tertiary institutions on the growth and socio-economic development of selected settlements in Ife North Local Government Area (LGA) of Osun State, Nigeria. In view of this, the study identified socio-economic activities; examined factors that contributed to the growth and development; and discussed the effects of the growth and development of the selected settlements in Ife North LGA. Data for the study were obtained from both primary and secondary sources. Data were analysed using Concentration Index (CI) and descriptive statistics of mean, standard deviation and variance. Results showed that apart from the location of higher institutions, other factors that were identified as significant to the growth and development of the study area include peaceful coexistence and the creation of Ife North LGA. In addition, the impacts of the location of the institutions are mostly felt in Asipa $(\mathrm{CI}=1.6410)$ and Edunabon $(\mathrm{CI}=1.5708)$. However, results indicated that the most perceived influence of the location of higher institutions in the area were increase in house rent, increase in crime rates and other social vices. The private sector was found to be more active in the development of the selected settlements in Ife North LGA. In view of these observations, the study concluded that location of higher institutions of learning in the less developed parts of a developing country like Nigeria, presents both a series of challenges and openings for scholars working in urban areas. Therefore, the study recommended that, for the institutions to serve their roles as growth centres there is the need for a joint collaboration between the public and the private sectors to increase their levels of participation in the development of small urban centres.
\end{abstract}

Key words: Concentration index, growth and development, central place, regional growth pole, growth centre, small urban centres, 


\section{INTRODUCTION}

The concepts of central place and regional growth pole were developed to offer deductive explanations about the significance of service centres in a region. Christaller (1933) posited that a central place is a settlement that constitutes itself into a position of authority with respect to its control of the generators and diffusers of impulses of development. As such, other settlements that consistently have disproportionately smaller shares of the indicators than of population are regarded as peripheries or zones of influence. Therefore, the main function of a central place is to supply goods and services to the surrounding population. Its influence is undertaken with its market area and the size of this market area will determine the nature of the spatial order. However, there are some central places with location that favour them to cater for more people and offer more specialized services. Such settlements tend to grow progressively larger, their size depending on their degree of specialization, therefore producing various types of sub-centres with different populations and zones of influence.

Perroux (1955) contends that at the centre there are certain indicators of growth, or geographic agglomeration of activities as modified by Boudeville (1966), and activities whose productive capacities influence the performance of other activities in the economy. There is hardly a region without such centres, because, regional organization needs constant movement of people, goods, and information to maintain it. Weber and Puissant (2002) attributed this to the excess of inward movement that bring about change, while decreased movement leads to contractions and development of ghost cities. But growth is characteristically physical and socio-economic. Döring and Schnellenbach (2006) assert that a region is said to be growing when there is presence of increased physical and socio-economic elements such as good roads, commercial and recreational centres, health centres, industries, electricity supply, housing and institutions. Thus, the more the functions a town performs, the more rapid is the growth into a large population centre and the greater the variety of functions. This also increases the numbers of jobs it provides for the people who are attracted to it. Thus, the urban centre becomes point of intense economic activities, which in turn could extend to beyond such boundaries into the surrounding areas.

Roy (2009) corroborated by Myers (2011) observed that the growing critiques of urban theory necessarily articulate the need to generate new conceptual vectors that engage with actually existing urban conditions in the developing world. However, Swilling (2011) reiterated that in the past, spatial analysis for regional development had been constrained by three other problems: the failure to recognize the importance of spatial factors in national and regional resource development; lack of an operational framework for integrated spatial analysis; and the paucity and unreliability of data in rural regions for formulating effective development plans. Robinson and Parnell (2011) showed that as marginalized urban dwellers confront multiple inequalities and difficulties in accessing resources, they often intervene in arrangements of infrastructure in order to shift socio-environmental conditions and metabolisms of energy and other resource flows that sustain urban life.

Wei (2007) opined that the social, economic, and ecological ramifications of future development of human settlement will depend upon specific spatial patterns exhibited by the settlements in relationship to existing communities, infrastructure services, vegetation and habitat types, and watershed boundaries. But the pattern and composition of spatial systems and the roles of various types of settlements differ drastically among developing nations, and any serious effort to shape spatial systems to promote more equitable and widespread development, especially in marginal zones, requires careful analysis and planning. Dong et al. (2007) pointed out two of the dangers of inappropriate development policies in marginal regions. First, they noted that these areas are not necessarily ecologically marginal and that the ecological stability of more populated and developed regions often depends on the stability of marginal areas. Major disruptions of ecological systems in marginal areas could have adverse effects on more developed areas of the country. Moreover, if development is inappropriate or ill-considered it would likely leave people in marginal regions worse off and more alienated. Grant (2009) noted that marginal area 
populations are particularly susceptible to this kind of situations because their resource systems and ways of life are often radically different from those of more developed areas. There is, therefore, a real likelihood for increased poverty, alienation and cultural disintegration under conditions of radical disruption.

The focus on the location of service centres, such as higher institutions of learning, presents both a series of challenges and openings for scholars working in urban areas, particularly in the less developed economies like Nigeria (Jinadu, 2006; Robinson, 2006; Simone, 2013). While the location of industries and other services or activities in a place could lead to rapid physical expansion and socio-economic growth, they could be used to bring development to an entire area (Simone, 2013). Tewari (1992) submitted that spatial planning of services and infrastructural facilities has become an important area of concern. He opined that concentrating investments in services and infrastructure in settlements that serve, or could serve, a large population from surrounding areas is more efficient and effective than scattering services and facilities widely over the landscape. Tewari (1992) stressed further that such method will assist regional planners and policy makers in locating services and facilities requiring different economies of scale and population thresholds in towns that could serve as growth centres for regional economic development. Edsenor and Jayne (2011) opined that location of service centres can thus be understood as in-the making, undergoing constant adjustment and intervention, and in a permanent state of flux. This ceaseless reconfiguration of urban networks is thus an important site to map conditions of possibility and from which to analyse the socio-material production of cities (Loftus, 2012; Lawhon et al., 2014).

Marianov and Serra (2004) considered the location of facilities or services in discrete space or networks that are related to the public sector, such as emergency services (ambulances, fire stations, and police units), school systems and postal facilities. They advised that when planning public facilities, it may be necessary not only to obtain a good location, but to achieve also a balanced demand assignment level. They stressed further that in order to be efficient, facilities need to have a minimum demand threshold level. Marianov and Serra (2004) particularly mentioned the provision of services that are considered merit goods, but that are services by the private sector as an area of application where the concept of threshold is relevant. According to them, this is especially relevant for merit services that have been publicly owned or controlled in several countries and are being transferred to the private sector, such as postal services, gas stations, fire departments and pharmacies. Marianov and Serra (2004) recommended that while the planner seeks to maintain good service quality by keeping a balanced spatial distribution of services, these need to have a minimum service threshold level that will allow them to survive.

Nuzir and Dewancker (2014) consider higher education institute or university as one of the important education facilities. They noted that since the ancient Greece, Rome, India, and China, education has always been a significant part of society development as the changing factor into a civilization. In a more specific manner, Nuzir and Dewancker (2014) re-echoed Japan as a country which has limited natural resources and has been experiencing aging and declining of its population. Therefore, in order to maintain its economic growth, Japan is using its science and technology advantages as its main generator. They noted that education in Japan plays important roles in the development of the economy and the society. Furthermore, they observed that the development of various education facilities contributes substantially to the development of an urban area. Nuzir and Dewancker (2014) concluded that Kitakyushu Science and Research Park is one of the examples that the coordination between the community, industries and universities is contributing to the development of Kitakyushu City.

In spite of all the afore-mentioned efforts at sustaining sustainable growth of small urban centres, growing critiques of urban theory production articulate the need to generate new conceptual vectors that engage with actually existing urban conditions (Grant, 2009; Songsore, 2009). These critiques call for additional research on the emergent urban futures being generated in the poor urban spaces. This has led to the research task of investigating socio-economic needs of 
settlements undergoing development process. Planners and investors in the socio-economic systems provide important ways in which to transform, both incrementally and at a larger scale, infrastructure conditions and address multiple development issues being faced by urban centres such as small urban settlements (Robinson, 2006; Myers, 2011; Robinson and Parnell, 2011; Lawhon et al., 2014).

Hence, this study seeks to contribute to such work through a detailed reflection of informal urban systems and the influence of locating service centres, particularly, higher institutions of learning in small urban centres on the socio-economic lives of the inhabitants. In effect, the study aimed at assessing the influence of the location of higher institutions of learning on the physical growth and socio-economic development of selected settlements in Ife North Local Government Area of Osun State, Nigeria. In view of this, the study identified the types of socio-economic facilities in the selected settlements in Ife North Local Government Area of Osun State before and after the establishment of educational institutions in the area; trace-out the extent of physical growth of the study settlements before and after the establishment of educational institutions in the area; examine other factor(s) contributing to the growth and development of the study area; and discuss the effects of the growth and development of the study area.

\section{THE STUDY AREA}

The study was conducted in Ife North Local Government Area (LGA) of Osun State, Nigeria. Ife North LGA is located between latitudes $6^{\circ} 58^{\prime}$ and $7^{\circ} 35^{\prime} \mathrm{N}$ and longitudes $4^{\circ} 22^{\prime}$ and $4^{\circ} 37^{\prime}$ E (figure 1). The LGA is made up of what is historically referred to as "Origbo meje" (Seven Sister towns) and a large number of smaller settlements. The "Seven Sister" settlements are: Moro, Yakooyo, Edunabon, Ipetumodu, Asipa, Akinlalu and Isope (figure 1). The headquarters of Ife North Local Government Area is at Ipetumodu.

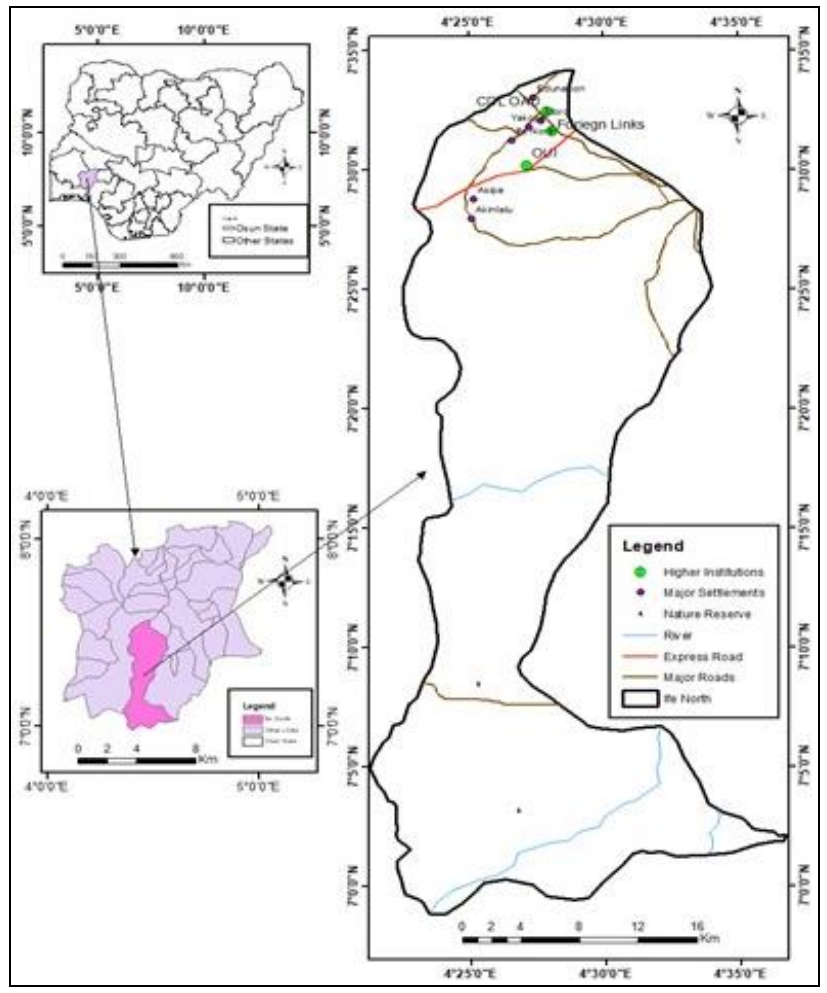

Figure 1. The Study Area 
Ife North LGA has a land area of is approximately 884.906 square kilometres (Osun State, 2012). The population of inhabitants of the study area are heterogeneous in nature. The people in the study area comprised mostly of the Yoruba speaking people (Oyo, Ife and Ijesa accents). Others include some Hausa, Igbo, Urhobo, Filani etc. Human population in Ife North LGA has never been static; it has been increasing at increasing rate. In 1991, the population of the area was 127, 677 which increased to 153,694 in 2006 (National Population Commission, 1991, 2006).

The present relief of the area is a product of the past and continuous weathering process, giving rise to a considerable reduction in height in the centre of the town. Outcrops vary from place to place mainly as a result of their varying resistance to erosion but outcrops are common on granite-gneisses while they are rare on schist (Adejuwon and Jeje, 1975; Adejuwon, 2005). The area is drained by River Shasha and River Ogbe, a tributary of River Opa. The soil of Ife North is derived from the materials of old basement complex, which is mainly made up of granites, metamorphosed rocks and sedimentary rocks (Adejuwon, 2005). The most significant category of soils in the area consists of alluvial and colluvial soils along the river valleys, which is regarded as the best cocoa soils in western Nigeria (Adejuwon and Jeje, 1975; Osunade, 1992).

The Local Government Area is located within the rain forest belt of Nigeria where the climate is humid tropical characterised by high temperature, high rainfall, and high relative humidity (Adejuwon et al., 1992; Adejuwon, 2005). It is characterised by marked wet (April to October) and dry season which usually begins towards the end of October and ends around March. The mean monthly temperature ranges between $23^{\circ} \mathrm{C}$ and $27^{\circ} \mathrm{C}$. The relative humidity is very high between $67 \%$ and $88 \%$. This climate supports rainforest formation and encourages the growth of cash crops such as cocoa, kolanut, and oil palm (Ojo, 1977; Adejuwon et al., 1992). In effect of these geographic attributes, farming and some other kinds of agro-allied activities such as lumbering and saw-milling are the major occupations of the inhabitants of Ife North Local Government Area. Thus, the LGA is a major collection centre for agricultural products which has attracted traders from Northern Nigeria to settle and trade, especially in kolanut. Other non-farm human activities are gold-smiting, carpentry, soap making and pot making. In addition, some of the inhabitants are involved in small scale business activities.

\section{MATERIALS AND METHODS}

Data for this study were obtained from both primary and secondary sources. However, the study relied heavily on primary data which were generated through household questionnaire. Secondary data were obtained from the political map of the study area prepared by the Town Planning Division of Ife North Local Government Area (2010).

Four settlements that were directly affected by the location of higher institutions in Ife North LGA, Nigeria were selected for the study. These settlements are: Ipetumodu, Edunabon, Moro and Asipa. A total of 302 representing 5\% of the total heads of households in the study area were sampled (table 1). Selection of residential housing units for the study was based on the principles of stratified sampling technique. By this, each of the selected settlements was divided into three blocks tagged $\mathrm{A}, \mathrm{B}$, and $\mathrm{C}$. While Block ' $\mathrm{A}$ ' represents the old core of the settlement where the oldest buildings are found, Blocks ' $\mathrm{B}$ ' and ' $\mathrm{C}$ ' are the intermediate and the outskirt zones, respectively. In view of the observed inequalities in the number and density of buildings and for easy identification of sample points within the study area, each of the blocks were further divided into ten quadrants of equal sizes based on the current Township Map prepared by Planning Division of Ife North LGA. In each of the cells, based on the principles of systematic sampling method employed, every kth dwelling housing unit was selected as sample point. The size of kvalue depended on the number of houses contained in each cell (Eq. 1).

$$
\mathrm{K}=\mathrm{N} / \mathrm{n}
$$

Where: $\mathrm{k}$ is the sampling interval

$\mathrm{N}$ is the number of households / dwelling housing unit (per settlement)

$\mathrm{n}$ is the number of elements contained in the sample (per street) 
In every building, only the head of household was interviewed and filled a copy of the household questionnaire. However, there were exceptional cases like multi-household buildings (more than one household occupying only one building), only the oldest household (in terms of age of residing in the house) was sampled. In addition, where there was multi-building single household (a single household occupying more than one building), which is a common feature of the traditional Yoruba settlements; the head of the household was sampled.

Table 1. Sample Selection in Ife North Local Government Area

\begin{tabular}{|c|c|c|c|c|c|c|}
\hline \multirow{2}{*}{ S/n } & \multicolumn{2}{|c|}{ Population } & \multicolumn{2}{c|}{$\begin{array}{c}\text { Number } \\
\text { of Households }\end{array}$} & $\begin{array}{c}\text { Sample Size } \\
\text { (based on 2017 } \\
\text { Estimates) }\end{array}$ \\
\cline { 3 - 6 } & & $\begin{array}{c}\mathbf{1 9 9 1} \\
\text { Census }\end{array}$ & $\begin{array}{c}\mathbf{2 0 1 7} \\
\text { Estimate* }\end{array}$ & $\begin{array}{c}\mathbf{1 9 9 1} \\
\text { Census }\end{array}$ & $\begin{array}{c}\mathbf{2 0 1 7} \\
\text { Estimate* }\end{array}$ & \\
\hline & Ipetumodu & 20,472 & 36,440 & 1,304 & 2,320 & 116 \\
\hline & Edunabon & 7,196 & 12,809 & 877 & 1,560 & 78 \\
\hline & Moro & 3,613 & 6,431 & 652 & 1,160 & 58 \\
\hline & Asipa & 2,629 & 4,680 & 562 & 1,000 & 50 \\
\hline \multicolumn{2}{|c|}{ Total } & 33,910 & 60,360 & 3,395 & 6,040 & 302 \\
\hline
\end{tabular}

* 2006 Census Results are not available on settlement basis; all estimates were based on 1991 Census Results at the official growth rate of $3 \%$ per annum.

Data obtained from various sources were analysed using statistical and cartographic methods. The influence of the location of higher institutions of learning on the physical growth of selected settlements in the study area was assessed using Concentration Index (CI, Eq. 2).

$$
\mathrm{CI}=\text { ni } \mathrm{X} 100 / \text { pi X } 100
$$

$$
\sum \mathrm{N} \quad \sum \mathrm{P}
$$

Where, $\mathrm{CI}=$ Concentration Index

$\mathrm{ni}=$ number of facility " $\mathrm{i}$ ” (under consideration) in location $\mathrm{i}$

$\mathrm{pi}=$ population of location " $\mathrm{i}$ "

$\sum \mathrm{N}=$ total number of facility " $\mathrm{i}$ " in the whole are (e.g. total sample settlements)

$\sum \mathrm{P}=$ total population of sample settlements

\section{RESULTS AND DISCUSSION}

Table 2 shows that Ipetumodu, the administrative headquarters of the LGA, was the most populous centre in the area with 20,472 people in 1991 which was estimated to be 36,440 in 2017. Edunabon, the second largest settlement, contained less than half of the headquarters' population size.

Table 2. Population Growth of the Selected Settlements in Ife North LGA Data sources: ${ }^{*}$ Census Results, ${ }^{* *}$ Projection at official 3.0\% annual growth rate (based on 1991 Census)

\begin{tabular}{|c|c|c|c|}
\hline $\mathbf{S} / \mathbf{n}$ & Settlement & $\mathbf{1 9 9 1}^{*}$ & $\mathbf{2 0 1 7}^{\text {** }}$ \\
\hline 1. & Ipetumodu & 20,472 & 36,440 \\
\hline 2. & Edun Abon & 7,196 & 12,809 \\
\hline 3. & Moro & 3,613 & 6,431 \\
\hline 4. & Asipa & 2,629 & 4,680 \\
\hline
\end{tabular}

\section{SOCIO-ECONOMIC FACILITIES IN IFE NORTH LOCAL GOVERNMENT AREA}

Table 3 indicates that Ipetumodu, the administrative headquarters of Ife North LGA had the highest number of socio-economic facilities in the study area. The most abundant facilities are elementary schools and supermarkets. 
Table 3. Socio-Economic Facilities in Selected Settlements in Ife North LGA Source: Field Research, 2017

\begin{tabular}{|c|c|c|c|c|c|c|}
\hline \multirow{2}{*}{$\mathbf{S} / \mathbf{n}$} & \multirow{2}{*}{ FACILITIES } & \multicolumn{4}{|c|}{ SETTLEMENTS } & \multirow{2}{*}{ TOTAI } \\
\hline & & Ipetumodu & Edunabon & Moro & Asipa & \\
\hline 1. & Daily Markets & 1 & 0 & 1 & 0 & 2 \\
\hline 2. & Periodic Market & 1 & 1 & 0 & 1 & 3 \\
\hline 3. & Supermarket & 9 & 3 & 2 & 4 & 18 \\
\hline 4. & Small Scale Industry & 5 & 7 & 2 & 0 & 14 \\
\hline 5. & Elementary School & 11 & 9 & 3 & 3 & 26 \\
\hline 6. & Sec. School & 5 & 4 & 1 & 2 & 11 \\
\hline 7. & Tertiary Institution & 2 & 0 & 1 & 0 & 3 \\
\hline 8. & Financial Institution & 1 & 1 & 0 & 0 & 2 \\
\hline 9. & Health Centre & 6 & 3 & 1 & 2 & 12 \\
\hline 10. & Post Services & 1 & 1 & 0 & 0 & 2 \\
\hline 11. & Police Station & 1 & 1 & 0 & 0 & 2 \\
\hline 12. & Electricity & 1 & 1 & 1 & 1 & 4 \\
\hline 13. & Piped-water & 1 & 1 & 1 & 1 & 4 \\
\hline 14. & Hotel/Rest House & 4 & 4 & 1 & 2 & 11 \\
\hline 15. & Tarred Road & 1 & 1 & 1 & 1 & 4 \\
\hline 16. & Students Hostels & 5 & 1 & 5 & 2 & 13 \\
\hline 17. & L. G. Secretariat & 1 & 0 & 0 & 0 & 1 \\
\hline 18. & Filling Station & 4 & 2 & 1 & 0 & 7 \\
\hline & TOTAL & 60 & 40 & 21 & 19 & 140 \\
\hline
\end{tabular}

\section{Factors Influencing the Growth and Development of the Study Area}

Analysis of the growth and development of selected settlements in Ife North LGA was attempted through the analyses of the roles of public and private sectors and concentration index of each of the facilities. The analysis is based on the availability and provider of the eighteen socioeconomic facilities contained in table 3.

\section{Ownership of Socio-Economic Facilities in Ife North LGA}

Table 4 shows that the private sector was more active in the development of the selected settlements in Ife North LGA. However, the provision of electricity, piped water, police station, post office, Local Government Secretariat and tarred roads were solely the responsibilities of government. In like manner, markets, financial institutions, industrial establishments, hotels, filling stations and students' hostels were provided by the private sector. Of the three campuses of institutions of higher learning, two (Oduduwa University and Foreign Links) were provided by the private sector while one, OAU - Centre for Distance Learning, is owned by the Federal Government. It is important to mention that of the three public secondary schools in Ipetumodu, one is owned by the Federal Government.

\section{Concentration Index of Socio-economic Facilities in Ife North LGA}

Table 5 shows that Ipetumodu and Edunabon had the highest number of educational institutions in the study area. However, the concentration index of educational institutions was very high in Asipa and Edunabon. This implies that the impacts of the location of the institutions are mostly felt in Asipa (1.6410) and Edunabon (1.5708). 
Table 4. Ownership of Socio-Economic Facilities in the Study Area Source: Field Research, 2017

\begin{tabular}{|c|c|c|c|c|c|c|c|c|c|c|}
\hline \multirow{2}{*}{$\mathbf{s} / \mathbf{n}$} & \multirow{2}{*}{ FACILITIES } & \multicolumn{2}{|c|}{ Ipetumodu } & \multicolumn{2}{|c|}{ Edunabon } & \multicolumn{2}{|c|}{ Moro } & \multicolumn{2}{|c|}{ Asipa } & \multirow{2}{*}{ TOTAL } \\
\hline & & Pub & Priv & Pub & Priv & Pub & Priv & Pub & Priv & \\
\hline 1. & Daily Markets & 0 & 1 & 0 & 0 & 0 & 1 & 0 & 0 & 2 \\
\hline 2. & Periodic Market & 0 & 1 & 0 & 1 & 0 & 0 & 0 & 1 & 3 \\
\hline 3. & Supermarket & 0 & 9 & 0 & 3 & 0 & 2 & 0 & 4 & 18 \\
\hline 4. & Small Scale Industry & 0 & 5 & 0 & 7 & 0 & 2 & 0 & 0 & 14 \\
\hline 5. & Elementary School & 3 & 8 & 3 & 6 & 1 & 2 & 1 & 2 & 26 \\
\hline 6. & Sec. School & 3 & 2 & 1 & 3 & 1 & 0 & 1 & 1 & 12 \\
\hline 7. & Tertiary Institution & 0 & 2 & 0 & 0 & 0 & 1 & 0 & 0 & 3 \\
\hline 8. & Financial Institution & 0 & 1 & 0 & 1 & 0 & 0 & 0 & 0 & 2 \\
\hline 9. & Health Centre & 2 & 4 & 0 & 3 & 1 & 0 & 1 & 1 & 12 \\
\hline 10. & Post Services & 1 & 0 & 1 & 0 & 0 & 0 & 0 & 0 & 2 \\
\hline 11. & Police Station & 1 & 0 & 1 & 0 & 0 & 0 & 0 & 0 & 2 \\
\hline 12. & Electricity & 1 & 0 & 1 & 0 & 1 & 0 & 1 & 0 & 4 \\
\hline 13. & Piped-water & 1 & 0 & 1 & 0 & 1 & 0 & 1 & 0 & 4 \\
\hline 14. & Hotel/Rest House & 0 & 4 & 0 & 4 & 0 & 1 & 0 & 2 & 11 \\
\hline 15. & Tarred Road & 1 & 0 & 1 & 0 & 1 & 0 & 1 & 0 & 4 \\
\hline 16. & Students Hostels & 0 & 5 & 0 & 1 & 0 & 5 & 0 & 2 & 13 \\
\hline 17. & L. G. Secretariat & 1 & 0 & 0 & 0 & 0 & 0 & 0 & 0 & 1 \\
\hline 18. & Filling Station & 0 & 4 & 0 & 2 & 0 & 1 & 0 & 0 & 7 \\
\hline & TOTAL & 14 & 46 & 9 & 31 & 6 & 15 & 6 & 13 & 140 \\
\hline
\end{tabular}

Pub. $=$ facilities provided by Government (of various tiers)

Priv. $=$ facilities provided by private individuals/community/corporate bodies

Table 5. Concentration Index of Higher Institutions in Ife North LGA Source: Field Research, 2017

\begin{tabular}{|c|c|c|c|c|c|c|c|}
\hline \multirow{2}{*}{ Settlements } & \multirow{2}{|c|}{ Population } & \multicolumn{7}{|c|}{$\begin{array}{c}\text { Percentage of Total } \\
\text { Concentration Index })\end{array}$} \\
\cline { 2 - 8 } & $\begin{array}{c}\text { Educational } \\
\text { Institutions }\end{array}$ & $\begin{array}{c}\text { Health } \\
\text { Centres }\end{array}$ & Industries & $\begin{array}{c}\text { Relaxation } \\
\text { Centres }\end{array}$ & Markets & $\begin{array}{c}\text { Financial } \\
\text { Institutions }\end{array}$ \\
\hline Ipetumodu & 36,440 & $43.6(0.7219)$ & $\begin{array}{c}50.0 \\
(0.8278)\end{array}$ & $\begin{array}{c}35.7 \\
(0.5911)\end{array}$ & $\begin{array}{c}36.4 \\
(0.6026)\end{array}$ & $\begin{array}{c}40.0 \\
(0.6623)\end{array}$ & $\begin{array}{c}33.3 \\
(0.5513)\end{array}$ \\
\hline Edunabon & 12,809 & $33.3(1.5708)$ & $\begin{array}{c}25.0 \\
(1.1792)\end{array}$ & $\begin{array}{c}50.0 \\
(2.8535)\end{array}$ & $\begin{array}{c}36.4 \\
(1.7170)\end{array}$ & $\begin{array}{c}20.0 \\
(0.9434)\end{array}$ & $\begin{array}{c}33.3 \\
(1.5708)\end{array}$ \\
\hline Moro & 6,431 & $10.3(0.9626)$ & $\begin{array}{c}8.3 \\
(0.7757)\end{array}$ & $\begin{array}{c}14.3 \\
(1.3364)\end{array}$ & $\begin{array}{c}9.1(0.8505) \\
(1.8692)\end{array}$ & $\begin{array}{c}20.0 \\
(3.112 .3\end{array}$ \\
\hline Asipa & 4,680 & $12.8(1.6410)$ & $\begin{array}{c}16.7 \\
(2.1410)\end{array}$ & $\begin{array}{c}0.0 \\
(0.0000)\end{array}$ & $\begin{array}{c}18.2 \\
(2.3333)\end{array}$ & $\begin{array}{c}20.0 \\
(2.5641)\end{array}$ & $0.0(0.0000)$ \\
\hline
\end{tabular}

The impact of health services on the growth and development of the study area is most visible in Asipa with just two health centres. Whereas the index of concentration in Asipa is 2.1410 , it is as low as 0.8278 in Ipetumodu with six health centres (table 5). Also, there were very view industrial establishments in the study area. The fourteen industrial plants were small-scale 
industries such as bakery, block-making, food processing (palm oil and gaari) and local craft activities. On the whole, the concentration index of industrial activities was highest in Edunabon (2.3585) with seven establishments (table 5). Table 5 reveals further that Asipa had no industrial establishment and, thus, the concentration index was 0.0000 . The concentration index of relaxation centres in Ife North LGA indicates that hotel was just the only type of such facility in the study area. There were eleven hotels in the area with Asipa having the highest index of 2.3333. The lowest impact was on Ipetumodu with four hotels and an index of 0.6026 (table 5).

In addition, table 5 shows the concentration index of markets in Ife North LGA. The markets considered in this study are the traditional open markets; both daily and periodic. The development impacts of markets were mostly felt in Asipa (2.5641) and Moro (1.8692). Ipetumodu with two markets had a concentration impact of 0.6623 . Distribution of financial institutions in Ife North LGA shows that each of Ipetumodu, Edunabon, and Moro had one financial institution. The institution in Moro was necessarily one ATM centre at the CDL campus. Asipa was the only settlement among the selected ones that had no financial institution. The impact of financial institutions was highest in Moro with an index of 3.1121 (table 5).

Using descriptive statistics of mean, standard variation and variance, the contribution of the factors to the growth and development of the study area was attempted. Table 6 presents these values in descending order of mean value. The most important factor as identified by the respondents is the location of higher institutions with a mean value of 64.75, standard deviation (18.590) and variance (345.583). Peaceful co-existence and the creation of Ife North Local Government Area with the headquarters at Ipetumodu were also identified as significant factors at mean values of 48.00 and 35.25, respectively. Factors such as existence of good markets (14.75), good health services (13.75), availability of social and entertainment facilities (9.50), provision of infrastructural facilities (8.25), availability of financial institutions (3.75) and existence of industrial activities (2.00) were rated as less important to the growth and development of the study area.

Table 6. Factors Influencing Growth and Development of the Study Area Source: Field Research, 2017

\begin{tabular}{|c|c|c|}
\hline $\mathrm{S} / \mathrm{n}$ & Factors & $\begin{array}{c}\text { Mean } \pm \text { SD } \\
(\text { Min - Max })\end{array}$ \\
\hline 1. & Location of Higher Institutions & $\begin{array}{c}64.8 \pm 18.6 \\
(47-78)\end{array}$ \\
\hline 2. & Peaceful Co-existence & $\begin{array}{c}48.0 \pm 21.3 \\
(28-78)\end{array}$ \\
\hline 3. & Creation of Local Government Area & $\begin{array}{c}35.3 \pm 20.8 \\
(19-65)\end{array}$ \\
\hline 4. & Opportunity for Business Diversification & $\begin{array}{c}34.8 \pm 10.8 \\
(25-49) \\
\end{array}$ \\
\hline 5. & Good Life Security & $\begin{array}{l}25.0 \pm 9.0 \\
(12-31) \\
\end{array}$ \\
\hline 6. & Cheap Land & $\begin{array}{c}23.5 \pm 14.5 \\
(12-43)\end{array}$ \\
\hline 7. & Closeness to Large Cities & $\begin{array}{l}19.8 \pm 1.5 \\
(18-21) \\
\end{array}$ \\
\hline 8. & Existence of Good Markets & $\begin{array}{c}14.8 \pm 7.5 \\
(7-25) \\
\end{array}$ \\
\hline 9. & Good Health Services & $\begin{array}{c}13.8 \pm 9.3 \\
(1-23) \\
\end{array}$ \\
\hline 10. & Availability of Social and Entertainment & $\begin{array}{l}9.5 \pm 5.1 \\
(2-13) \\
\end{array}$ \\
\hline 11. & Provision of Infrastructural Facilities & $\begin{array}{l}8.3 \pm 7.1 \\
(2-18)\end{array}$ \\
\hline 12. & Availability of Financial Institutions & $\begin{array}{l}3.8 \pm 5.7 \\
(0-12) \\
\end{array}$ \\
\hline 13. & Existence of Industrial Activities & $\begin{array}{c}2.0 \pm 0.8 \\
(1-3) \\
\end{array}$ \\
\hline
\end{tabular}




\section{Socio-economic Impacts}

The perceptions of respondents on the impacts of the location of higher institutions in the selected settlements in Ife North Local Government Area, Nigeria indicate multiple responses as each respondent was somewhat restricted to state, and somehow free, to select the perceived impacts. Therefore, the total responses are not equal for all cases and in all settlements.

Table 7. Perceptions of the Impacts of the Location of Higher Institutions in Ife North LGA Source: Field Research, 2017

\begin{tabular}{|c|c|c|c|} 
S/n & Influences & $\begin{array}{c}\text { Mean } \pm \text { SD } \\
\text { (Min }- \text { Max })\end{array}$ & Variance \\
\hline 1. & Increase in house rent & $\begin{array}{c}61.3 \pm 17.0 \\
(43-82)\end{array}$ & 288.3 \\
\hline 2. & Increase in crime rates and other social vices & $\begin{array}{c}56.0 \pm 13.1 \\
(43-74)\end{array}$ & 172.7 \\
\hline 3. & Diversification of business activities & $\begin{array}{c}47.0 \pm 20.7 \\
(25-75)\end{array}$ & 429.3 \\
\hline 4. & Conversion of building/part to business premises & $\begin{array}{c}46.8 \pm 15.0 \\
(31-67)\end{array}$ & 224.3 \\
\hline 5. & Increase in the indigenes' interest in education & $\begin{array}{c}35.3 \pm 4.2 \\
(31-41)\end{array}$ & 17.6 \\
\hline 6. & Increase in profit & $\begin{array}{c}35.0 \pm 21.1 \\
(14-59)\end{array}$ & 444.7 \\
\hline 7. & Restructuring of housing units to modern style & $22.8 \pm 11.6$ & $(12-39)$ \\
\hline 8. & Provision of social facilities & $\begin{array}{c}17.3 \pm 5.7 \\
(11-23)\end{array}$ & 134.3 \\
\hline
\end{tabular}

Table 7 presents the mean values and the standard variations of the perceptions of respondents on the impacts of the location of higher institutions in the selected settlements in Ife North Local Government Area. The most perceived influence is increase in house rent with a mean value of 61.25, standard deviation (16.978) and variance (288.250). The pair of increase in crime rates and other social vices was rated as the second important influence of the location of higher institutions of learning in Ife North LGA. It had a mean value of 56.00, standard deviation (13.140) and variance (172.667). Provision of social facilities was less significant in the assessment of influence of the location of higher institutions of learning in Ife North LGA. The mean value of this impact was just 17.25, standard deviation (5.679) and variance of 32.250. This implies that the location of higher institutions in the area has very little impact on the provision of social facilities.

\section{DISCUSSION}

This study was conducted in some selected settlements in Ife North Local Government Area of Osun State, Nigeria. The study aimed at assessing the influence of the location of higher institutions of learning on the growth and socio-economic development of selected settlements in Ife North Local Government Area of Osun State, Nigeria. To achieve this aim, the study was set against the background of identifying the types of socio-economic activities; examined factors that contributed to the growth and development; and discussing the effects of the growth and development of the selected settlements in Ife North Local Government Area of Osun State. The settlements selected for the study were those that were directly influenced by the location of higher institutions in the area. These are: Ipetumodu, Edunabon, Moro and Asipa.

The study found out that there were different kinds of socio-economic facilities in Ife North Local Government Area of Osun State, Nigeria. However, Ipetumodu, the administrative 
headquarters of Ife North LGA had the highest number of socio-economic facilities in the study area. The most abundant facilities are elementary schools and supermarkets. Incidentally, these two facilities, elementary schools and supermarkets, were the most abundant in the whole area. It was also gathered that, although the provision of certain basic services like electricity, piped water, police station, post office, Local Government Secretariat and tarred roads were solely the responsibilities of government, yet the private sector was found to be more active in the development of the selected settlements in Ife North LGA. However, the provision of such amenities like markets, financial institutions, industrial establishments, hotels, filling stations and students' hostels were provided by the private sector.

Descriptive statistics of mean, standard variation and variance were adopted to explain the contributing factors to the growth and development of the study area. The most important factor as identified by the respondents is the location of higher institutions with a mean value of 64.75 , standard deviation (18.590) and variance (345.583). Peaceful co-existence and the creation of Ife North Local Government Area with the headquarters at Ipetumodu were also identified as significant factors at mean values of 48.00 and 35.25, respectively. Factors such as existence of good markets (14.75), good health services (13.75), availability of social and entertainment facilities (9.50), provision of infrastructural facilities (8.25), availability of financial institutions (3.75) and existence of industrial activities (2.00) were rated as less important to the growth and development of the study area. With the Concentration Index results, it implies that the impacts of the location of higher institutions in Ife North LGA are mostly felt in Asipa (1.6410) and Edunabon (1.5708).

\section{CONCLUSION}

Based on the foregoing, it is safe to conclude that the study of the location of higher institutions of learning in the less developed country like Nigeria, presents both a series of challenges and openings for scholars working in urban areas. On the whole, this study has shown that: higher institutions could stimulate regional development when they are located as growth centres; with the results of increase in crime rates and other social vices (mean $=56.00, \mathrm{SD}=13.140$ and variance $=172.667$ ), it implies that the location of higher institutions could also be a threat to the residents of the area where they are located; the private sector (the community) was more concerned about their welfare than the government and despite the creation of a Local Government in the study area much has not been achieved to really assess the area as a central place.

In view of the observed laxities in the study area, the study recommends that, for the institutions to really serve their roles as growth centres there is the need for a joint collaboration between the public and the private sectors to increase their levels of participation in the development of small urban centres like the selected settlements in Ife North Local Government Area of Osun State, Nigeria. It is also recommended that, in the attempt not to disrupt the peaceful co-existence and the perceived life security in the study area, it is necessary to intensify security efforts. This, again, can be achieved through public-private collaborations.

\section{REFERENCES}

Adejuwon, J. O., \& Jeje, L. K. (1975). Land element of the environmental system of Ife area (No. 2). Environment Resource Base Project, Department of Geography, University of Ife.

Adejuwon, J. O., Balogun, E. E., \& Adejuwon, S. A. (1990). On the annual and seasonal patterns of rainfall fluctuations in sub-Saharan West Africa. International Journal of Climatology, 10(8), 839-848.

Adejuwon, J. O. (2005). An Introduction to Geography of the Tropics. Hong Kong: Nelson.

Boudeville, J. R. (1966). Problems of regional economic planning. Edinburgh: Edinburgh UP.

Christaller, W. (1966). Central places in southern Germany. Prentice Hall.

Dong, W., Zhang, X., Wang, B., \& Duan, Z. (2007). Expansion of Ürümqi urban area and its spatial differentiation. Science in China Series D: Earth Sciences, 50(1), 159-168.

Döring, T., \& Schnellenbach, J. (2006). What do we know about geographical knowledge spillovers and regional growth?: A survey of the literature. Regional Studies, 40(03), 375-395. 
Edensor, T., \& Jayne, M. (2011). A World of Cities: Urban Theory Beyond the West, London: Routledge.

Grant, R. (2009). Globalizing city: The urban and economic transformation of Accra, Ghana. Syracuse University Press.

Jinadu, A. M. (2006). Patterns of Settlement Interactions in the FCT: Implications for Settlement Development Planning. Journal of the Nigerian Institute of Town Planners, 28, 67 - 86.

Lawhon, M., Ernstson, H., \& Silver, J. (2014). Provincializing urban political ecology: Towards a situated UPE through African urbanism. Antipode, 46(2), 497-516.

Loftus, A. (2012). Everyday environmentalism: creating an urban political ecology. University of Minnesota Press.

Marianov, V. \& Serra, D. (2004) New Trends in Public Facility Location Modeling. SSRN Electronic Journal, DOI:10.2139/ssrn.563843

Myers, G. (2011). African cities: Alternative visions of urban theory and practice. London: Zed Books.

National Population Commission of Nigeria (1991). Results of 1991 Population Census.

National Population Commission of Nigeria (2006). 2006 National Population Census Results.

Nuzir, F. A., \& Dewancker, B. J. (2014). Understanding the role of education facilities in sustainable urban development: A case study of KSRP, Kitakyushu, Japan. Procedia Environmental Sciences, 20, 632-641.

Ojo, O. (1977). The Climate of West Africa. Heineman: London.

Osun State Government of Nigeria (2012). Osun State Statistical Year Book. Osogbo: Government Press.

Osunade, M. A. (1992). Identification of crop soils by small farmers of South-western Nigeria. Journal of Environmental Management, 35(3), 193-203.

Perroux, F. (1955). Note sur la notion de pole de croisssance. economie appliquée. Economie Appliquee, (8), 1 \& 2: $307-320$. (Translated by Mette Monsted, (1974).

Robinson, J. (2006). Ordinary cities: Between modernity and development. London: Routledge.

Robinson, J., \& Parnell, S. (2011). Traveling theory: Embracing post-neoliberalism through Southern cities. The new Blackwell companion to the city, 521-531.

Roy, A. (2009). The 21st-century metropolis: New geographies of theory. Regional Studies, 43(6), 819-830.

Simone, A. (2004). People as infrastructure: intersecting fragments in Johannesburg. Public culture, 16(3), 407-429.

Simone, A. M. (2013), Cities of uncertainty: Jakarta, the urban majority, and inventive political technologies. Theory, Culture and Society, 30(7), 243-263.

Songsore, J. (2009). The urban transition in Ghana: urbanization, national development and poverty reduction. London: IIED.

Swilling, M. (2011). Reconceptualising urbanism, ecology and networked infrastructures. Social Dynamics, 37(1), 78-95.

Tewari, V. K. (1992). Improving access to services and facilities in developing countries. International Regional Science Review, 15(1), 25-37.

Weber, C., \& Puissant, A. (2003). Urbanization pressure and modeling of urban growth: example of the Tunis Metropolitan Area. Remote sensing of environment, 86(3), 341-352.

Wei, Y. D. (2007). Regional development in China: Transitional institutions, embedded globalization, and hybrid economies. Eurasian Geography and Economics, 48(1), 16-36.

Submitted:

January 15, 2019
Revised:

June 15, 2019
Accepted and published online July 10, 2019 